\title{
The Use of Submerged-Arc Welding Flux Slag as Raw Material for the Fabrication of Multiple-Use Mortars and Bricks
}

\author{
(Uso de Escória de Fluxo de Soldagem a Arco Submerso como Matéria-Prima para a Fabricação de Argamassas de Múltiplo \\ Uso e Tijolos)
}

\author{
Caroline Espinosa Viana ${ }^{1}$, Dylmar Penteado Dias ${ }^{1}$, José Nilson França de Holanda ${ }^{2}$, Ronaldo Pinheiro da Rocha Paranhos ${ }^{2}$ \\ ${ }^{1}$ UENF/LECIV/CCT, Campos dos Goytacaze-RJ, Brasil, carolineespinosa@gmail.com; dylmar@uenf.br \\ ${ }^{2}$ UENF/LAMAV/CCT, Campos dos Goytacazes-RJ, Brasil,holanda@uenf.br; paranhos@uenf.br
}

\begin{abstract}
This work has as objective to analyze the recycling possible uses of the slag of welding flux (SWF) in the civil construction. It was searched the liability of SWF as substitute of sand in the production of multiple-use mortars and clay for the production of ceramic bricks. SWF has origin in the submerged-arc welding (SAW), and have been used slags of the acid, neutral and basic types, according to its neutrality. Mortars have been made containing the three types of SWF and in addition a reference mortar made with sand. Physical and mineralogical characteristics of each SWF were studied, and the physical properties (consistency and density) and mechanical properties (compressive and tensile strengths) of the mortars were analyzed. Ceramic pieces have been made containing kaolinitic sedimentary clay up to $10 \mathrm{wt}$. \% of SWF. The pieces were prepared by uniaxial pressing and fired at $950^{\circ} \mathrm{C}$. The following properties after firing were determined: linear shrinkage, water absorption, apparent porosity, apparent density, and flexural strength. The results show that for multiple-use mortars, SWF reached excellent results, being an overall substitute for sand as fine aggregate. For ceramic bricks, SWF can also be used as partial substitute for red clay. Both applications of SWF significantly contributes for the reduction of the ambient impact: on one hand, reducing the extraction of natural sand and clay, on other hand, contributing for the reduction of the risk of ground water contamination due to the inadequate disposal of the SWF.
\end{abstract}

Keywords: Civil construction; Industrial residue; Multiple-use mortars; Recycling; Slag of welding flux.

Resumo: Este trabalho tem como objetivo avaliar possíveis usos para a reciclagem da escória de fluxo de soldagem (EFS) na construção civil. Foi pesquisada a possibilidade do uso da EFS como substituto da areia na produção de argamassas de múltiplo-uso e substituição da argila na produção de tijolos. A EFS tem origem na soldagem a arco submerso (SAS), e foram usadas escórias dos tipos ácida, neutra e básica, conforme sua neutralidade. As argamassas foram preparadas usando os três tipos de EFS e ainda uma argamassa de referência feita com areia. As características físicas e mineralógicas de cada EFS foram estudadas, e as propriedades físicas (consistência e densidade) e propriedades mecânicas (resistência à compressão e à tração) das argamassas foram analisadas. Corpos de prova cerâmicos foram preparados contendo argila caulinítica sedimentar com até 10\% em peso de EFS. Estes foram confeccionados por pressão uniaxial e calcinados a $950^{\circ} \mathrm{C}$. As seguintes propriedades após a queima foram determinadas: deformação linear, absorção de água, densidade aparente e resistência à flexão. Os resultados mostraram que para as argamassas de múltiplo-uso, a EFS atingiu resultados excelentes, podendo substituir totalmente a areia como agregado miúdo. Para os tijolos cerâmicos, a EFS também pode ser usada como substituto parcial da argila vermelha. Ambas as aplicações da EFS contribuem significativamente para a redução de impacto ambiental: por um lado, reduzindo a extração de areia natural e da argila e, por outro lado, contribuindo para a redução do risco de contaminação do subsolo devido ao despejo inadequado da EFS.

Palavras-chave: Construção civil; Resíduo industrial; Argamassas de múltiplo-uso; reciclagem; Escória de fluxo de soldagem.

\section{Introduction}

The submerged-arc welding process (SAW) is widely used in the metal-mechanic industry due to its operational facility and productivity. In Brazil, this process is used for the manufacturing of tubes, pressure vessels, boilers, heat exchanges, iron-making

(Recebido em 05/05/2009; Texto Final em 29/07/2009). equipments, ships, automotive parts and all sort of heavy equipments. In SAW, the heat source is supplied by an electric arc formed between the solid or tubular wire electrode and the work piece. The electric arc and the melted metal are completely covered and protected by the flux from the atmospheric contamination. The granulated flux is partially melted and generates a liquid protective slag layer, which is solidified in the sequence. This solid material is considered as being a waste material, and referred hereafter as slag of welding flux (SWF) [1]. The fluxes that originate the SWF can be classified according 
to its neutrality as acid, neutral or basic types [2]. In Brazil, it is estimated that the submerged-arc welding process generates about 500 tonnes per month of SWF [3].

Nowadays, the SWF waste has been mainly disposed in landfill sites, which cost money. Thus, there is interest of the industrial sector in search technological alternatives for the use of this abundant waste.

The ceramic industry, particularly the sector devoted for the manufacturing of civil construction materials, has been widely used as an alternative to the recycling of industrial wastes [4-6]. Some reasons in favor of recycling of industrial wastes as civil construction materials are: i) the ceramic industry uses large amounts of natural raw materials; ii) the main production processes are not greatly modified; iii) traditional ceramic products allows a large range of their chemical-mineralogical compositions and iv) some heavy metals or toxic substances can be encapsulated in the ceramic matrix.

The main objective of this work is to study the recycling of SWF waste as an alternative raw material in the manufacturing of ceramic products for civil construction such as multipleuse mortars and clay bricks. Emphasis is given to the waste characteristics and its effects on the technological properties of the ceramic products.

\section{Materials and methods}

\subsection{Materials}

The raw materials used in this work were the conventional components for the manufacturing of multiple-use mortars (cement, natural sand and water) and bricks (plastic sedimentary clay), besides the SWF waste.

Portland cement compound with blast-furnace slag (CPIIE32 type) was used. This cement has been ordinary used in the civil construction elements. River natural sand used was washed, dried for $24 \mathrm{~h}$ and sieved with the objective of its use as normal sand according to the ABNT NBR 7214 standard [7].

Plastic sedimentary clay from Campos-RJ (Brazil) region for making bricks was used $(<40$ mesh), which is predominantly kaolinitic [8], rich in $\mathrm{SiO}_{2}, \mathrm{Al}_{2} \mathrm{O}_{3}$ and $\mathrm{Fe}_{2} \mathrm{O}_{3}$.

Three samples of SWF waste collected in the metal-mechanic industry from south-eastern Brazil were used in the preparation

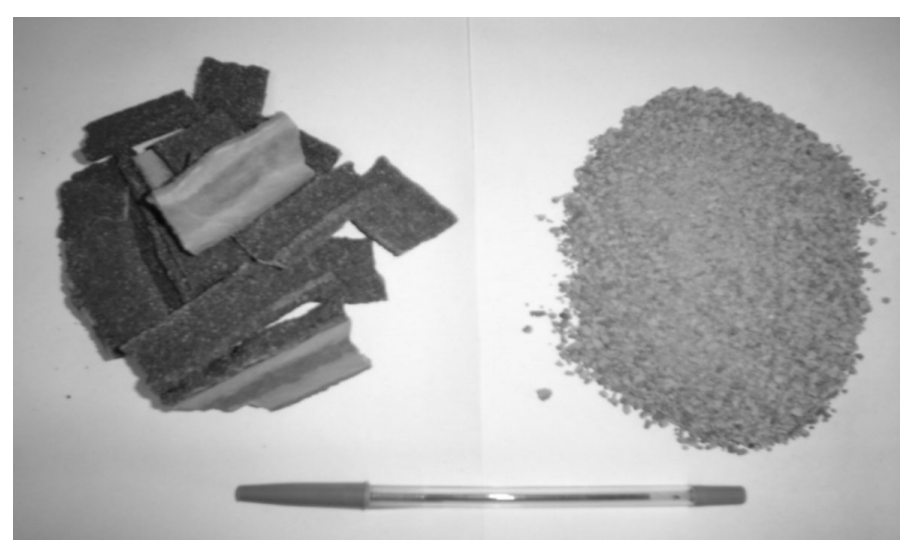

Figure 1. SWF waste before and after crushing. of the mortars. The samples were classified as acid SWF, neutral SWF and basic SWF, according to its neutrality. Waste samples were crushed and sieved, resulting in fine aggregate. Figure 1 shows the SWF waste before and after the crushing process. The particle size distribution of the SWF waste sample was determined. The mineralogy of the SWF samples was determined by X-ray diffraction (D5000 diffractometer, Siemens) using Cu$\mathrm{K}$ radiation. The unitary mass of the aggregates in the loose condition was determined according to ABNT NBR 7251 standard [9] and real specific mass determined according to ABNT NBR 9776 standard [10].

\subsection{Methodology}

Multiple-use mortars were prepared with the objective to characterize the use of SWF waste as fine aggregate. Four mortars samples were formulated: 1) reference mortar made with conventional fine aggregate (natural sand); 2) acid SWF mortar; 3) neutral SWF mortar and 4) basic SWF mortar. For the last three cases, natural sand was totally replaced by the corresponding SWF waste.

The mortars were prepared using a conventional mixer with capacity of 5 liters. The blended used was of 1:3 (cement to fine aggregate ratio, in weight). The cement to water relation was determined according with the standard consistency test [11]. The multiple-use mortars were characterized in terms of their consistency, fresh state density [12] and incorporated air content [12].

Mortar cylindrical specimens of size $50 \mathrm{~mm}$ x $100 \mathrm{~mm}$ were prepared to find out the compressive strength for 1, 3, 7, 28, 90 and 120 aging days. The compressive strength was determined according to ABNT NBR 13279 [13] using a hydraulic press (Versa Tester) at a loading of $0.5 \mathrm{MPa} \cdot \mathrm{s}^{-1}$. The tensile strength of the mortar cylindrical specimens of size $50 \mathrm{~mm} \times 100 \mathrm{~mm}$ was determined according to ABNT NBR 7215 [14] for 3, 7, 28, 90 and 120 aging days.

A series of clay and acid SWF waste mixtures were prepared. The bricks were made with up to 10 wt. $\%$ waste added as partial replacement of clay: sample S0 (reference sample, 0 wt. \% waste), sample S5 (5 wt. \% waste) and sample S10 (10 wt. \% waste). The ceramic formulations were dry mixed and homogenized using a cylindrical mixer, then uniaxially pressed at $24 \mathrm{MPa}$ into $115 \mathrm{~mm}$ x $254 \mathrm{~mm}$ bars, dried at $110^{\circ} \mathrm{C}$ for $24 \mathrm{~h}$, and fired at $950^{\circ} \mathrm{C}$ for a soaking time of $2 \mathrm{~h}$ in an electric furnace. The following technological properties were determined: linear shrinkage, water absorption, apparent porosity, apparent density and flexural strength according to standardized procedures.

\section{Results and discussion}

\subsection{Waste characteristics}

The results of X-ray diffraction of the SWF waste samples are given in Table 1. The following main mineralogical phases were identified: acid SWF waste (spinel - $\mathrm{MgAl}_{2} \mathrm{O}_{4}$ ), neutral SWF waste (fluorite - $\mathrm{CaF}_{2}$; periclase - $\mathrm{MgO}$; spinel $-\mathrm{MgAl}_{2} \mathrm{O}_{4}$ ) and basic SWF waste (calcite- $\mathrm{CaCO}_{3}$; calcium hydroxide - $\mathrm{Ca}(\mathrm{OH})_{2}$ ). 
These results are in accordance with the flux compositions that originated the SWF samples [2]. As can be observed, the acid flux contains high content of magnesium and aluminum oxides, the neutral flux is rich in fluorite and magnesium and aluminum oxides, while the basic flux is rich in calcium compounds.

Table 1. Mineralogical characterization of the SWF waste.

\begin{tabular}{l|c}
\hline \multicolumn{1}{c|}{ Samples } & Crystalline phases \\
\hline Acid SWF & $\mathrm{MgAl}_{2} \mathrm{O}_{4}$ \\
\hline Neutral SWF & $\mathrm{CaF}_{2} ; \mathrm{MgO}_{2}$ and $\mathrm{MgAl}_{2} \mathrm{O}_{4}$ \\
\hline Basic SWF & $\mathrm{CaCO}_{3}$ and $\mathrm{Ca}(\mathrm{OH})_{2}$ \\
\hline
\end{tabular}

The results of unitary specific mass and bulk density, as shown in Table 2, presented only slight differences. As compared with natural sand, however, the SWF waste samples are about $20 \%$ more dense. The SWF waste was crushed in order to obtain a fine aggregate material. It was determined that $98 \%$ of the SWF particles are $<4.8 \mathrm{~mm}$, which characterize the efficiency of the granulation process used. It was used SWF with Brazilian Normal Sand distribution [7] in the manufacture of the mortars (fineness module equal to 2.50).

Table 2. Unitary specific mass, bulk density and fineness module of the fine aggregates.

\begin{tabular}{l|c|c}
\hline \multicolumn{1}{c|}{ Samples } & $\begin{array}{c}\text { Unitary specific mass } \\
\left(\mathrm{g} \cdot \mathrm{cm}^{-3}\right)\end{array}$ & $\begin{array}{c}\text { Bulk density } \\
\left(\mathrm{g} \cdot \mathrm{cm}^{-3}\right)\end{array}$ \\
\hline Acid SWF & 2.65 & 3.38 \\
\hline Neutral SWF & 2.74 & 3.38 \\
\hline Basic SWF & 2.67 & 3.26 \\
\hline Natural sand & 1.39 & 2.62 \\
\hline
\end{tabular}

\subsection{Properties of the mortars}

The results of consistency and water content of the prepared mortars are shown in Table 3 . The cement to fine aggregate ratio of the mortars was kept at 1:3. The water-cement ratio was kept at 0.56 for the sand and neutral SWF samples, 0.52 for the acid SWF sample and 0.48 for the basic SWF sample.

The consistency index is an important property of the multipleuse mortars. The range of the consistency index specified in the ABNT NBR 13276 standard [11] is $255 \pm 10 \mathrm{~mm}$. As shown in Table 3, the consistency specification was achieved for all studied mortars. It can also be observed that the natural sand and neutral SWF samples presented equal values of water content, and approximate values of consistency index. These results are very important because indicate that the consistency of the mortars remained practically constant with the substitution of the natural fine aggregate. Thus, the mortar workability was not affected when SWF waste replaced natural sand.

The mortars made with SWF waste, as shown in Table 4, presented higher fresh state density. This can be attributed to the higher density of the SWF than the natural sand and the minor amount of incorporated air obtained. It was also verified that the mortars with larger water content present less incorporated air. The multiple-use mortars are classified according to the ABNT NBR 13281 standard [15] as: i) type $a$ (incorporated air $<8 \%$ ); ii) type $b$ (incorporated air between 8 to $18 \%$ ) and iii) type $c$ (incorporated air $>18 \%$ ).

The results show clearly that the mortar mixtures made with SWF waste presented a classification equal or superior the traditional mortar prepared with natural sand.

Table 3. Consistency index and water content of the mortars.

\begin{tabular}{l|c|c}
\hline Mortars / Mix proportions & Water content $(\%)$ & Consistency $(\mathrm{mm})$ \\
\hline Acid SWF / 1:3:0.52 & 13 & 260 \\
\hline Neutral SWF / 1:3:0.56 & 14 & 250 \\
\hline Basic SWF / 1:3:0.48 & 12 & 257 \\
\hline Natural sand / 1:3:0.56 & 14 & 245 \\
\hline
\end{tabular}

Table 4. Fresh state density and incorporated air of the mortars.

\begin{tabular}{l|c|c|c}
\hline $\begin{array}{c}\text { Mortars / Mix } \\
\text { proportions }\end{array}$ & $\begin{array}{c}\text { Fresh state density } \\
\left({\left.\mathrm{g} . \mathrm{cm}^{-3}\right)}^{-1}\right.\end{array}$ & $\begin{array}{c}\text { Incorporated air } \\
(\%)\end{array}$ & $\begin{array}{c}\text { ABNT NBR 13281 } \\
\text { standard [15] }\end{array}$ \\
\hline Acid SWF / 1:3:0.52 & 2.41 & 8 & Type b \\
\hline Neutral SWF / 1:3:0.56 & 2.51 & 2 & Type a \\
\hline Basic SWF / 1:3:0.48 & 2.34 & 10 & Type b \\
\hline Natural sand / 1:3:0.56 & 2.02 & 10 & Type b \\
\hline
\end{tabular}

The compressive strength is another important property used to verify the production uniformity and control of cements and mortars [16]. Figure 2 shows the compressive strength of the mortars. The results showed that all mortars presented mechanical strength above the values specified ( $\geq 8 \mathrm{MPa}$ - Class III) according to ABNT NBR 13281 [15].

Figure 2 also shows that the compressive strength increases with the increase of the aging time for all mortars. In addition, 
the mortars made with SWF waste presented higher compressive strength, for all aging times, than the ordinary mortar made with natural sand. The basic SWF mortar (1:3:0.48) presented the best mechanical strength, reaching $39 \mathrm{MPa}$ after 28 days and 49 MPa after 120 days aging, because the less water/cement ratio used.

Thus, mortars using SWF waste of any type (acid, neutral or basic) as fine aggregate can be made with full replacement of natural sand.

Figure 3 shows the results of tensile strength of the mortar specimens. It can be observed that the mortar with acid SWF (1:3:0.52) and with neutral SWF (1:3:0.56) presented very close tensile strengths, and the basic SWF (1:3:0.48), as a result of the lowest water-cement ratio, presented the higher tensile strength than the other ones.

The results also show that all mortars made with SWF waste presented higher tensile strength than the mortar made with natural sand.

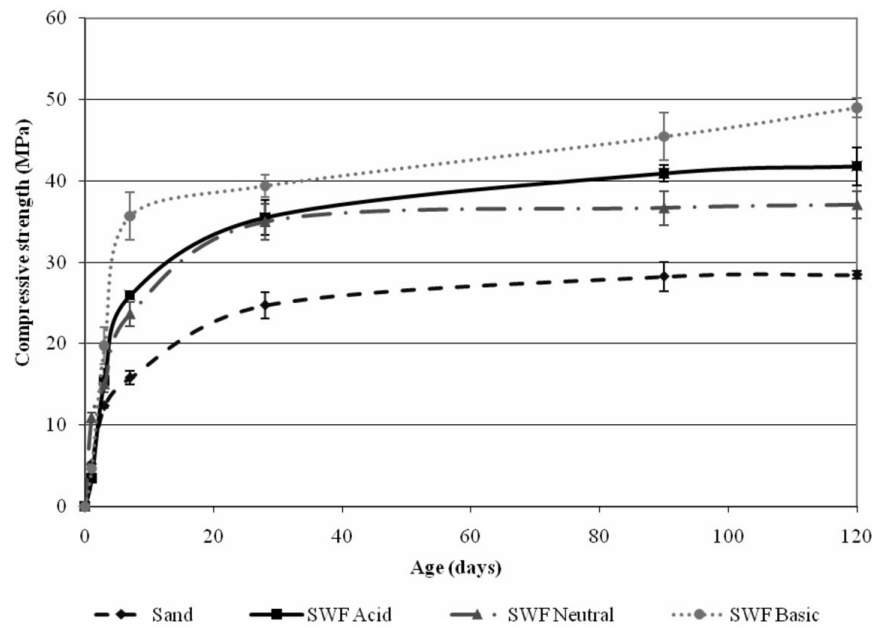

Figure 2. Compressive strength of the mortars.

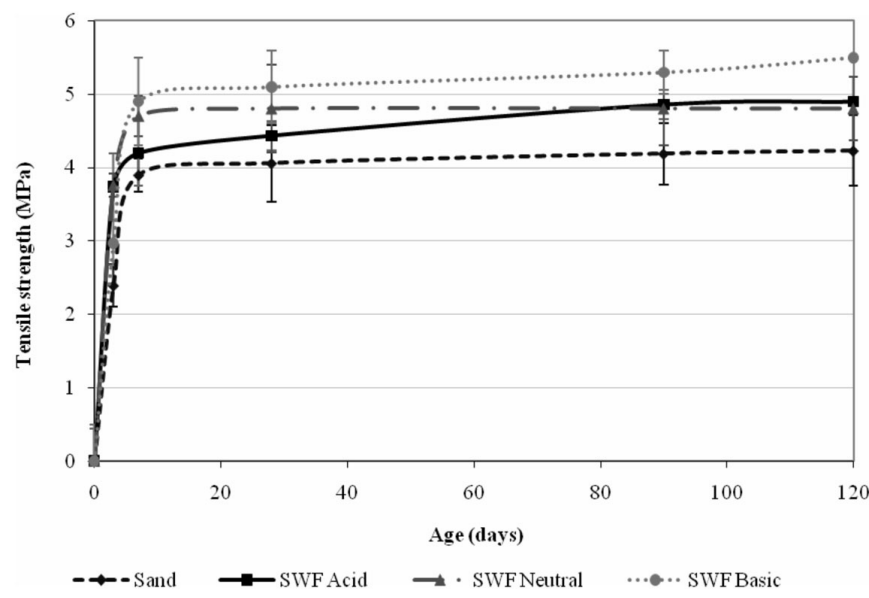

Figure 3. Tensile strength of the mortars.

It is important to emphasizes that the transformation of periclase $(\mathrm{MgO})$ into brucite, $\mathrm{Mg}(\mathrm{OH})_{2}$ (expansive and deleterious product), due to slow hydration process, was not presented by the mortar with neutral SWF, even after 120 days of age.

\subsection{Properties of the clay bricks}

The quality of the clay bricks incorporated with acid SWF waste, fired at $950^{\circ} \mathrm{C}$, was evaluated by measuring the following physical-mechanical properties: linear shrinkage, water absorption, apparent porosity, apparent density, and flexural strength (Figures 4 to 8 ). The linear shrinkage of the specimens, as shown in Figure 4, increased with waste addition. This was attributed to the chemical-mineralogical composition of the waste, which contributes to increase the sintering degree of the specimens. In addition, the values of linear shrinkage (1.81 to $2.46 \%$ ) are within the acceptable range for industrial production of clay bricks.

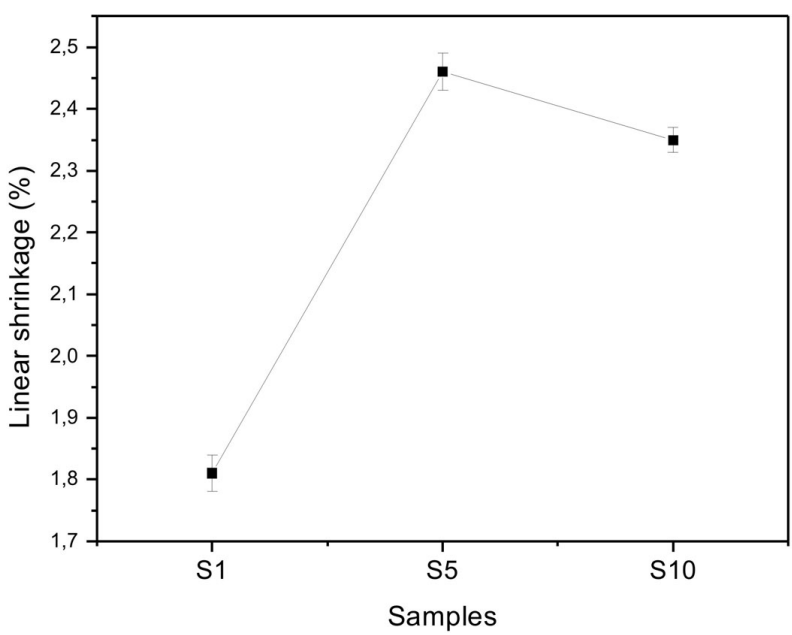

Figure 4. Linear shrinkage of the ceramic bricks.

The water absorption of the prepared bricks is shown in Figure 5. The results show that there are not restrictions for incorporation of SWF waste in clay bricks (water absorption < 25\%). The apparent porosity, as shown in Figure 6, presented similar behavior to water absorption.

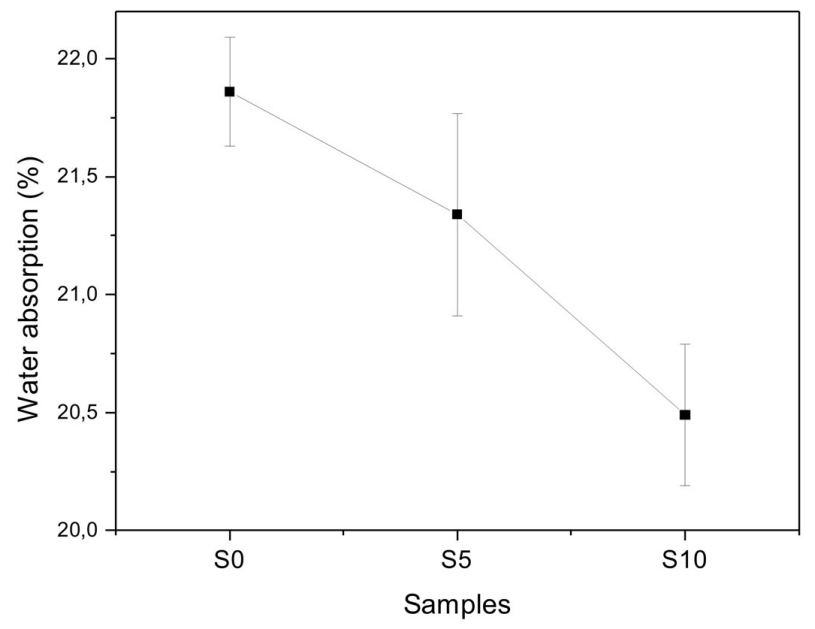

Figure 5. Water absorption of the ceramic bricks. 


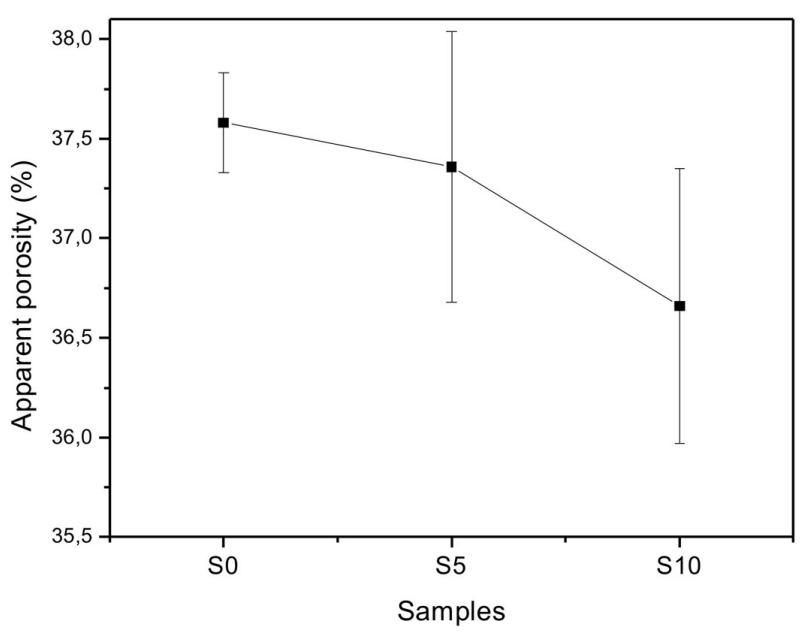

Figure 6. Apparent porosity of the ceramic bricks.

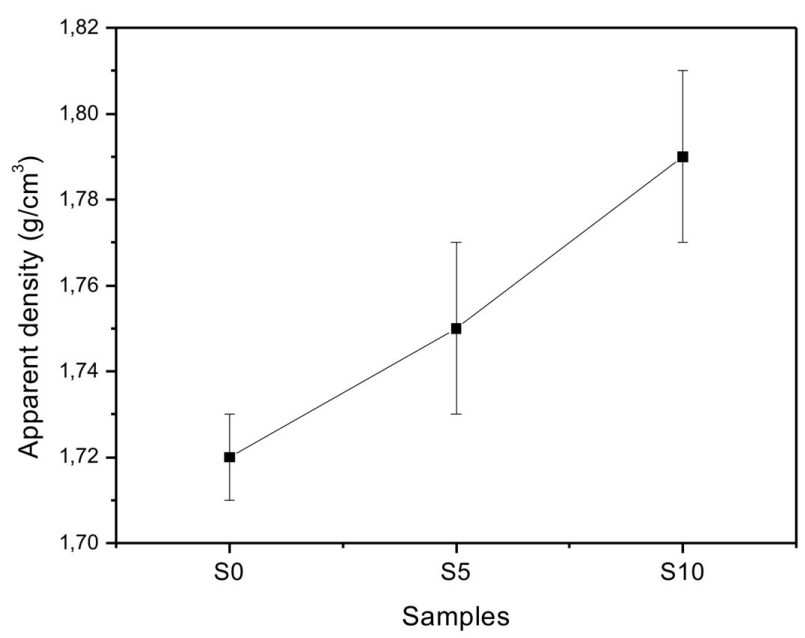

Figure 7. Apparent density of the ceramic bricks.

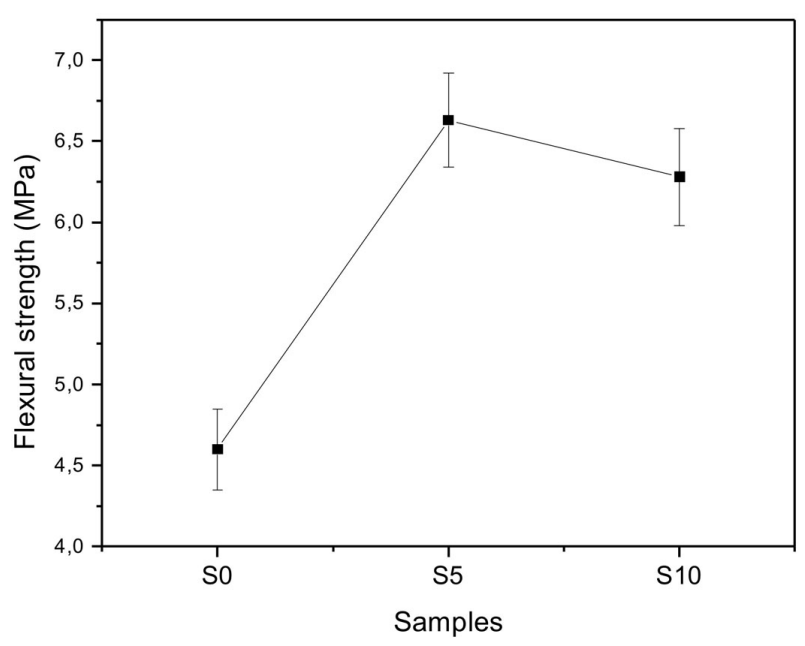

Figure 8. Flexural strength of the ceramic bricks.
The apparent density of the bricks is shown in Figure 7. As expected, the apparent density increases with waste addition. This is caused mainly by open-pore closure, resulting in better densification of the bricks.

The flexural strength of the bricks is shown in Figure 8. The effect of the incorporation of the SWF waste was to increase the mechanical strength of the bricks. This is related to the higher densification of the bricks.

\section{Conclusions}

Based on the experimental results, the following conclusions can be drawn:

- the three SWF waste samples (acid, neutral, and basic) presented all requirements for use as fine aggregate in multiple-use mortars according to the ABNT NBR 13281 standard [15];

- the mortars made with SWF waste, when compared to the ordinary mortar made with natural sand, presented equal or better behavior, measured by means of technological properties as consistency, fresh state density, incorporated air content and mechanical strengths;

- the SWF waste can be used as an alternative raw material for manufacturing of clay bricks. It was demonstrated that the technological properties of the bricks incorporated with up to 10 wt. \% of SWF waste replacing clay are compatible with those specified for ceramic bricks.

\section{Acknowledgements}

The authors acknowledge the CNPq and Tecnorte/Fenorte for financial support, and to the Machado Viana Comércio e Indústria Ltda - Caldeiraria, Usinagem e Fundição, and Alborg Industries by the supply of the welding flux slags.

\section{References}

[1] MODENESI, P. J. Técnica operatória da soldagem SAW, UFMG/DEMM, http://www.infosolda.com.br/artigos/prosol04. pdf. Acessado em janeiro de 2005.

[2] PARANHOS, R. P. R.; SOUZA A. C. Soldagem a arco submerso. Rio de Janeiro: SENAI/RJ-CETEC de Solda, 1999. $77 \mathrm{p}$.

[3] MORETE, G. F.; PARANHOS, R. P. R.; HOLANDA J. N. F. Aproveitamento de resíduo de escória de soldagem em materiais cerâmicos para construção civil, Soldagem \& Inspeção, v.11, n. 3, p. 141-146, 2006.

[4] DONDI, M.; MARSIGLI, M.; FABBRI, B. Recycling of industrial and urban wastes in brick production - a review, Tile \& Brick International, v. 13, p. 218-225, 1997.

[5] MIRANDA, L. F. R.; SELMO, S. M. S. Desempenho de revestimentos de argamassa com entulho reciclado. Boletim Técnico da Escola Politécnica da USP/DECC - BT/PCC/277, São Paulo, 2001. 12 p.

[6] MENEZES, R. R.; NEVES, G. A.; FERREIRA, H. C. O estado da arte sobre o uso de resíduos como matérias-primas 
cerâmicas alternativas, Revista Brasileira de Engenharia Agrícola e Ambiental, v. 11, n. 2, p. 303-313, 2002.

[7] ASSOCIAÇÃO BRASILEIRA DE NORMAS TÉCNICAS. NBR 7214: Areia normal para ensaio de cimento - especificação. Rio de Janeiro, 1982.

[8] SOUZA, G. P.; SOUSA, S. J. G.; TERRONES, L. A. H.; HOLANDA, J. N. F. Mineralogical analysis of ceramic sedimentary clays used in red ceramic, v. 51 , n. 320 , p. 180-186, 2005.

[9] ASSOCIAÇÃO BRASILEIRA DE NORMAS TÉCNICAS. NBR 7251: Agregado em estado solto - determinação da massa unitária. Rio de Janeiro, 1982.

[10] ASSOCIAÇÃO BRASILEIRA DE NORMAS TÉCNICAS. NBR 9776: Agregados: determinação da massa específica de agregados miúdos por meio de frasco de Chapman. Rio de Janeiro, 1987.

[11] ASSOCIAÇÃO BRASILEIRA DE NORMAS TÉCNICAS. NBR 13276: Argamassa para assentamento de paredes e revestimento de paredes e tetos - determinação do teor de água para obtenção do índice de consistência-padrão. Rio de Janeiro, 1985.

[12] ASSOCIAÇÃO BRASILEIRA DE NORMAS TÉCNICAS. NBR 13278: Argamassa para assentamento de paredes e revestimento de paredes e tetos - determinação da densidade de massa e do teor de ar incorporado. Rio de Janeiro. 1995.

[13] ASSOCIAÇÃO BRASILEIRA DE NORMAS TÉCNICAS. NBR 13279: Argamassa para assentamento de paredes e revestimento de paredes e tetos - determinação da resistência à compressão. Rio de Janeiro. 1995.

[14] ASSOCIAÇÃO BRASILEIRA DE NORMAS TÉCNICAS. NBR 7215: Cimento Portland - determinação da resistência à compressão. Rio de Janeiro. 1996.

[15] ASSOCIAÇÃO BRASILEIRA DE NORMAS TÉCNICAS. NBR 13281: Argamassa industrializada para assentamento de paredes e revestimento de paredes e tetos - especificação. Rio de Janeiro, 2001.

[16] NAKAKURA, E. H.; CINCOTTO, M. A. Análise dos requisitos de classificação de argamassas de assentamento e revestimento. Boletim técnico da Escola Politécnica da USP/ DECC, São Paulo, 2004. 